\title{
Effective Learning Strategies in Biology Online Learning to Anticipate Covid-19: A Literature Review
}

\author{
Desi Andyhapsari ${ }^{1, *}{ }^{*}$ Djukri ${ }^{2}$ \\ ${ }^{1}$ Master of Biology Education, Faculty of Mathematics and Natural Sciences, Universitas Negeri Yogyakarta, \\ Indonesia \\ ${ }^{2}$ Department of Biology Education, Faculty of Mathematics and Natural Sciences, Universitas Negeri \\ Yogyakarta, Indonesia \\ *Corresponding author.Email: desiandyhapsari.2019@student.uny.ac.id
}

\begin{abstract}
The Coronavirus disease (Covid-19) has a very broad impact and continues to spoil all aspect of life and presents its challenges, especially in the world of education. All forms of conventional learning activities are replaced by distance learning which is known online. The application of online learning itself requires readiness for various parties, both from teachers, students, and parents. Educators must be able to teach by utilizing complex online media that are packaged effectively, easily accessible, and of course, make it easier for students to understand the material. Creativity in designing learning strategies is the key to the success of an educator to be able to motivate students to remain enthusiastic in distance learning and not become a psychological burden. This research method was carried out by conducting a literature review of 40 journals. The literature on effective learning strategies to support biology online learning. This research technique uses a literature analysis. The results of the analysis show that an effective online biology learning strategy to be used or applied while remaining student-centered is $\mathrm{PjBL}$ learning, and blended learning assisted by online platforms, such as elearning, and Google Classroom. The application of these learning strategies can also improve cognitive, creative learning outcomes, thinking skills, learning satisfaction, and students learning biology independence. The platforms that can support online biology learning are education perfect, Ruangguru, and zenius education
\end{abstract}

Keywords: Literature review, Strategies in biology online learning

\section{INTRODUCTION}

The coronavirus pandemic (Covid-19) has hit 215 countries in the world[1], this event has a very broad impact and continues to destroy all aspects of life and provides its challenges, especially the world of education. This is because all forms of conventional learning activities in schools, colleges, and other educational institutions are eliminated. The Covid-19 pandemic in Indonesia itself has caused many schools and colleges to stop the face-to-face conventional learning process and replace it with distance or online learning. The government through the Ministry of Education and Culture is also trying to build cooperation with various parties and focus on developing an education system in the network (online)[2]. Learning changes made from face-to-face learning to distance learning result in a different learning experience for students [3].

The involvement and interaction between teachers and students during online learning is very important for students to build an understanding of new knowledge. However, distance learning causes poor interaction effects and low investment in learning during epidemics [4]. Therefore, the problems faced during this pandemic must be done immediately.

The application of online learning itself demands readiness for various parties, both from education service providers, parents, and students. The reason is that without careful preparation from various parties the transfer of distance learning activities cannot run properly and effectively. The government is currently implementing an emergency curriculum, which is a 
curriculum that is prepared to support the onlinebased learning process[2]. Also, educational institutions need to provide online technical guidance on the online implementation process and disseminate information to students and parents through print and social media about the procedures for implementing online learning, about their roles and duties.

In today's distance learning, of course, teachers must be ready to use technology by the times, because we know that the use of technology in learning does not always improve students' learning abilities, other terms or conditions are needed to create a learning environment that supports the implementation of the learning process. One of the less discussed areas of online education is the need of motivation for online learning[3]. Therefore, in the development of online learning the teacher must be able to make learning models and strategies that are following the character of students[5]. The use of several applications in online learning is very helpful for teachers in the learning process. Teachers must be able to teach by utilizing complex online media that are packaged effectively, easily accessible, and of course, make it easier for students to understand the material. The success of teachers in conducting online learning in the Covid-19 pandemic situation is the ability of teachers to innovate in activities to design and develop learning strategies starting from objectives, materials, learning methods, to assessments. Creativity is the key to the success of an educator to be able to motivate students to remain enthusiastic in distance learning and not become a psychological burden.

\section{METHODS}

The research method used is the method of literature review, namely information and The data collected was obtained from reviewing the literature in the form of existing articles previous research or research results that are considered valid which are sourced from references such as international journals and national journals related to the title of the article discussed. In addition, the reference content used is in the form of clear books[6].

Writing of this article uses the literature comparison method which is done by browsing literature online, consisting of books and journals related to learning strategies, learning methods, effective learning models during the pandemic. The steps used start from identification, article collection, and article selection according to the criteria. Identification is done by screening articles that must contain specific words, namely "online learning strategies", "biology learning" and "the effectiveness of online learning strategies". Then article collection is done by collecting articles as many as 40 journals that fit the criteria and the final step is selecting articles that pass the previous stage by checking the quality of the articles to analyzing the article as a result and discussing the article entitled "Effective Learning Strategies in Biology Online Learning to Anticipate Covid-19”.

\section{RESULTS AND DISCUSSION}

\subsection{Effective Learning Strategies in Biology Online Learning}

Strategy is a method or method used by educators to students to change the cognitive, affective, and motor aspects on an ongoing basis[7]. The learning strategy is carried out as a planning domain to identify all processes that will Educators carry out in implementing learning. Along with the development of the times, one of the learning strategies that has begun to be emphasized is constructivism, which requires students to be active in compiling and building their knowledge and understanding. Educators are not only givers of information to the students' thoughts, but educators must also encourage them to explore their world, find knowledge, reflect, and think critically[5]. In biology learning itself, it is not just the ability to explore and think critically that needs to be developed, but if it is related to $21 \mathrm{st}$ century learning, biology learning will emphasize the importance of mastering skills, namely critical, creative, communicative, and problem-solving thinking. Biology is the science of living things and their environment. From studying biology there are many benefits, in addition to the benefits there are impacts in the development of positive and negative biology for human life and the environment around[8] Biological scientific products are in the form of a collection of facts and concepts as a result of biological scientific processes. Learning biology if it is understood as learning science as a tracing process, then students should also be invited to be involved in the tracing process of discovery, so every teacher needs to understand as well as possible about the learning process of students, to provide guidance and provide an environment learning that is appropriate and suitable for students. Biology teachers will be required to have these skills in teaching their students so that students will be able to compete in this 21 st century. 
During the Covid-19 pandemic, online learning is a solution in implementing the learning process. The learning process for students must be done flexibly. The orientation no longer sees the learning outcomes but focuses on how the learning process goes well. Some of the effective learning strategies that can be done in implementing biology online learning are the application learning model project based and blended learning.

$\mathrm{PjBL}$ is a learning model that is suitable for learning activities from home because through $\mathrm{PjBL}$ students are invited to collaborate, be independent, and explore[9]. Online learning will certainly be less meaningful without the synergy of strategies and proper learning methods. One application that can integrate online learning is project-based learning[10]. PjBL has the main objective to provide training to students to be more able to collaborate, work together, and have empathy with others. PjBL can be the choice of an effective and appropriate learning model. Currently, more and more schools are using $\mathrm{PjBL}[9]$.

The $\mathrm{PjBL}$ strategy is used so that learning is learner-centered, the learning topics are matters relating to everyday life, in the implementation of learning tasks must produce real products, and these products are monitored by the teacher for input or evaluation. The first step in PjBL learning, namely, teachers and students compile basic questions related to the themes to be studied and worked on together, then compile a plan such as designing the needs for tools and materials, then make a schedule for the project at home. During the project at home, students record observations and the teacher monitors students via telephone, email, or learning applications. PjBL makes students thrive because when they learn in their way, they develop the ability to focus and reflect. Working in their way also provides an opportunity to take personal responsibility for what they learn [9].

The culmination of project-based learning is usually written or oral reports summarizing what was done and what the results were [11]. With such a final result, students will be motivated to develop their ability to explore independently. PjBL is very effective in motivating students to learn independently[11]. Students will be motivated to do project assignments without burden and get maximum results and become a practicum assessment. Through the PjBL model, there is an increase in motivation to learn Science [10]. Biology online learning with $\mathrm{PjBL}$ facilitates interaction between teachers and students. Interaction can occur effectively in project-based learning by utilizing the inquiry process by directing students to make or develop products that are applicable and related to everyday life so that students are facilitated to learn concepts in-depth and can improve learning outcomes[12]. Learning biology with the $\mathrm{PjBL}$ strategy also has a significant effect on problemsolving abilities[13], as well as encourages students to actively discuss while studying and while doing assignments[14]. Using the PjBL strategy in online learning makes it easy to transfer information in various situations and conditions[15]. This is of course with careful preparation, and teachers should be able to choose the right topic according to the $\mathrm{PjBL}$ model so that it can foster students' creativity and confidence[16].

Based on the results of research[17] the use of project-based learning has the potential to improve the cognitive learning outcomes of students with a kinesthetic learning style with a corrected mean value of cognitive learning outcomes of 85,459 . This shows that the cognitive learning outcomes of students taught with the PjBL model are higher than other models. Also, implementing PjBL in online learning currently still requires good preparation in planning. This is supported by[18] that the results of the reflection of sikluas I on the application of $\mathrm{PjBL}$ based on Mind Mapping in biology subjects have not progressed well which resulted in classical completeness not being achieved, but after preparing suggestions for supporting infrastructure for the learning process, preparing lesson plans and worksheets on the application of the sikluas II classical completeness has been achieved, which is more than $85 \%$. These broad differences make students foster their independent attitude. Because $\mathrm{PjBL}$ requires students to learn to find their knowledge in their work, they are invited to design their projects, are invited to determine the length of time for the work, and are invited to agree from the start about matters related to their project. These results are also in line with[19] where the average level of student completeness in the cognitive, affective and psychomotor domains is $90 \%$, with details of $90 \%$ cognitive, $97 \%$ affective and $89 \%$ psychomotor by applying the method Project Based Learning, these results indicate that The learning experience provided to students during the online learning period is not inferior to face-to-face learning. The success of students' learning experiences is also 
inseparable from the readiness of the teacher in designing online learning that is used, as is the case with[16] where the application of the model projectbased learning requires careful preparation, the teacher should be able to choose the right topic according to the model project-based learning so that creativity and students' self-confidence in learning can be obtained better.

PjBL has several advantages including 1) facilitating students to collaborate on conceptual understanding, applying initial knowledge, and higher-order thinking skills; 2) enable students to show higher abilities; 3) challenge students to solve real problems, be good collaborators; 4) motivate students, and 5) increase content knowledge, and meet the needs of students with various skills and learning styles [20].

Currently, technological advances are important for improving the quality of learning and research results. The research results are supported by various literature sources that can be accessed via the internet (online), and information in the form of discussion results is collected face-to-face offline. The combination of online and offline learning activities is called Blended Learning, which is a learning strategy by combining face-to-face learning and learning using online learning resources[21].

Blended learning fulfills all aspects to support the improvement of the quality of learning, has many positive impacts on the learning process but in its application, it has challenges including 1) Educators must have the ability or skills in using technology and require a lot of time in developing this learning method. Especially at the beginning of the implementation period, 2,) educators must be able to build material following the method and be able to build the learning process to answer and give statements in online classes[22]. Found that the learning experiences in an online environment brought about a positive attitude change concerning the use of the Web for learning among the students, regardless of the type of interaction[23]. found the use of this mixed learning environment to have a positive impact on reducing student dropout rates and improving their test scores[24]. besides mixed learning experiences can also strengthen students' understanding of the subject, improve and support their learning process[25].

The results of the study[20] show that blended learning and $\mathrm{PjBL}$ are quite influential in increasing creative thinking skills, $\mathrm{BL}$ and $\mathrm{PjBL}$ are quite effective compared to conventional learning in increasing creative thinking in biology learning. In line with research[26].

Blended learning is a learning solution in era of the new normal at this time, because online learning is increasingly popular, as well as a mixture of learning[27], the online methods that can be used as using multimedia both synchronous (synchronous) and asynchronous (asynchronous). Synchronous and asynchronous online learning to determine learners' perceptions of learning experiences and learning performance there is no significant difference in student satisfaction with their online learning experience in the two online groups. Overall shows very positive feelings[28]. Because the purpose of distance learning is done to achieve quality learning. Blended learning has configured itself in a new normal by offering the potential to enhance the teaching and learning process in an educational environment that is more responsive to the lifestyles of contemporary learners[29]. According to Horn \& Staker (2011) in [27]model blended learning that can be applied in online learning, namely the Online Platform Model where teachers and material are all online, with students taking courses remotely, faceto-face with the teacher is still required. In line with Haughey's opinion in the current pandemic, the blended learning used is the model, Web course namely the use of the Internet for educational purposes, in which students and educators are completely separate and face-to-face is not required. All teaching materials, discussions, consultations, assignments, exercises, exams, and other learning activities are completely delivered via the Internet.

The conditions of online learning in the new normal era certainly require teacher creativity and innovation in managing to learn, as well as the need for easy and flexible access to learning, so there is a need for the availability of teachers and students to carry out mixed learning. Using mixed learning allows the development of responsibility, criticality, teamwork, and autonomy of students, while one can innovate and make use of technology and information resources[30].

The implementation of blended learning effectively increases learning independence and can be alternative learning that can be used during the Covid-19 pandemic. One of them is the e-learning that is presented by blended learning which is an extension of the classroom that can be accessed by 
students anywhere and anytime[31]. Then this approach can also be supported by other platforms, such as LMS Google Classroom which provides support for Internet-based distance learning and supports the approach Blended Learning in learning biology[32]. Blended learning can also maintain or increase access for large groups of students and result in better success rates[29].

\subsection{Utilization of Support Platforms for The Continuation of The Online Learning Process during The Covid-19 Pandemic}

The current situation of the Covid-19 pandemic has allowed the government to implement measures in an effort to limit assembly and crowd activities. attempts or actions like this also interfere with the normal functioning of the school. Therefore, the government has certainly put in place alternative methods for teachers and students to continue faceto-face learning into distance learning, namely by applying them online.

In the education system there are 3 groups of resources, where these groups are divided according to their objectives, namely curriculum, professional development, and tools. In the three groups of resources that can support the implementation of online learning, namely curriculum resources. which in this curriculum includes lessons, videos, interactive learning modules. These curriculum resources directly support students in acquiring knowledge and abilities[33]. According to Reimers, et al (2020) several digital platform-based learning resources can be used to help teachers and students in learning biology online in Indonesia, namely as follows:

\subsubsection{Education Perfect}

Education Perfect is a learning platform that is adapted to the current curriculum, which includes science, mathematics, languages, etc. EP is created using a mastery model, which in the assessment will be adjusted to the learning progress of each student. the delivery of instructions on this platform can automatically select from material based on student competencies in various fields of study, and at various grade levels. The content that is developed will provide opportunities for students to be able to learn actively, think critically and independently, and collaboratively. besides, this platform can also be accessed by teachers. where the teacher can then access automated assessments and answers through demonstrations and peer reviews. Then for the assessment of student activeness, the teacher can see it through direct student involvement based on student participation in virtual classes.

\subsubsection{Ruangguru}

Ruangguru is a platform that provides free access, but not all content, only to online school tabs that include covered material for K-12. Through the use of this platform in helping students in online learning today, of course, it is expected to be able to support students' cognitive abilities in the realm of knowledge, then in students' interpersonal skills in the realm of group collaboration, as well as students' intrapersonal abilities in the realm of independence and responsibility.

\subsubsection{Zenius Education}

Similar to Ruangguru, Zenius is one of the largest EdTech platforms. This platform have many videos for preparatory examinations such as college entrance exams (UTBK) and national exams (UN). ZE also supports students' cognitive abilities in the realm of knowledge, then students' interpersonal skills in the realm of group collaboration, and then intrapersonal abilities in the realm of independence and responsibility.

\section{CONCLUSION}

Based on the results and discussion, it can be concluded that:

a. Based on the results and discussion above, it can be concluded that an effective biology online learning strategy to be used or applied during the current pandemic is $\mathrm{PjBL}$ learning, and blended learning The application of these learning strategies can also improve learning result as cognitive, creative learning outcomes, thinking skills, learning satisfaction, and students learning biology independence;

b. The platforms that can support online biology learning are education perfect, Ruangguru, and zenius education. These platforms help students gain additional knowledge from what educators have provided by being able to acquire cognitive (knowledge), interpersonal (group collaborative skills), and intrapersonal (work ethics and responsibility) abilities. 


\section{REFERENCES}

[1] B. Indrayana, A. Sadikin, Penerapan E-Learning Di Era Revolusi Industri 4.0 Untuk Menekan Penyebaran Covid-19, Indonesian Journal of Sport Science and Coaching 2(1) (2020) 47. DOI: https://doi.org/10.22437/ijssc.v2i1.9847

[2] Ministry of Education and Culture, Regulation of The Minister of Education and Culture No. 4 of 2020 concerning Implementation of Education Policies in An Emergency for The Spread of Covid-19, Jakarta, 2020.

[3] D.S. Bestiantono, P. Z. R. Agustina, T.-H. Cheng, How Students' Perspectives about Online Learning Amid the COVID-19 Pandemic?, Studies in Learning and Teaching 1(3) (2020) 49.4 DOI: http://www.doi.org/10.33902/JPSP. 2020261309

[4] X. Yang, M. Zhang, L. Kong, Q. Wang, J.-C. Hong, The Effects of Scientific Self-efficacy and Cognitive Anxiety on Science Engagement with 'Question-Observation-DoingExplanation' Model during Schools Disruption in COVID-19 Pandemic, Research Square, (2020) 2. DOI: https://doi.org/10.21203/rs.3.rs40814/v1

[5] H. Salim, Learning Strategy (An Approach of How to Transform Student's Learning Activities), Perdana, 2012, p. 167.

[6] B. Nur, S. Nurdiana, Video Based Learning sebagai Media Belajar Biologi Jarak Jauh Masa Kini Video-Based Learning as a Present Distance Learning Biology Media, in: Prosiding Seminar Nasional Biologi VI Harmonisasi Pembelajaran Biologi pada Era Revolusi 4.0, Universitas Negeri Makassar, Makassar, 2019, pp. 228-233.

[7] M.Y. Isnayni, W. Hermansyah, Pengaruh Pembelajaran Sistem Daring, ALVEOLI Jurnal Pendidikan Biologi 1(1) (2020) 22-28.

[8] F. Ferdinand, A. Moekti, Practical Learning Biology 1, Bookkeeping Center of the Ministry of National Education, 2009.

[9] C. Yuliana, Project Based Learning, Model Pembelajaran Bermakna di Masa Pandemi Covid 19, Lampung, 2020.

[10] L. Handayani, Peningkatan Motivasi Belajar IPA melalui Model Pembelajaran Project Based
Learning pada Masa Pandemi Covid-19 bagi Siswa SMP Negeri 4 Gunungsari, Jurnal Paedagogy 7(3) (2020) 168. DOI: https://doi.org/10.33394/jp.v7i3.2726

[11] M. Prince, R. Felder, The Many Faces of Inductive Teaching and Learning, Journal of College Science Teaching 36(5) (2007) 14-20.

[12] K. Arizona, Z. Abidin, R. Rumansyah, Pembelajaran Online Berbasis Proyek Salah Satu Solusi Kegiatan Belajar Mengajar Di Tengah Pandemi Covid-19, Jurnal Ilmiah Profesi Pendidikan 5(1) (2020) 64-70. DOI: http://www.doi.org/10.29303/jipp.v5i1.111

[13] W. Karmana, Strategi Pembelajaran, Kemampuan Akademik, Kemampuan Pemecahan Masalah, dan Hasil Belajar Biologi, Jurnal Ilmu Pendidikan 17(5) (2012). DOI: http://www.doi.org/10.17977/JIP.V17I5.2866

[14] I. Ramadhan, Analysis of Learning Models and Students' Learning Understanding on The Application of Online Learning in Islamic High School Nurul Fikri Boarding School Cinangka, Dissertation, Universitas Pendidikan Indonesia, 2020.

[15] R. Lestari, A. Syam, Strategi Pembelajaran Daring di Era Covid-19 untuk Menumbuhkan Kemampuan Berfikir Kreatif Mahasiswa di STKIP Pesisir Selatan, Jurnal Kepemimpinan dan Keperguruan Sekolah 5(2) (2020) DOI: http://www.doi.org/10.34125/kp.v5i2.538

[16] D.W. Nuryati, S. Masitoh, F. Arianto, Pengaruh Project Based Learning Terhadap Kreativitas Peserta Didik di Masa Pandemi, Educate: Jurnal Teknologi Pendidikan 5(2) (2020) 98-106. DOI:

http://www.doi.org/10.32832/educate.v5i2.3375

[17] F. Akbar, A. Bahri, Biology Teaching and Learning Efektivitas Model PjBL (Project Based Learning) dalam Meningkatkan Hasil Belajar Kognitif Peserta Didik dengan Gaya Belajar Berbeda, Biology Teaching and Learning 1(1) (2010) 71-80,

[18] N.L.R. Tirtawati, Isolasi Mandiri Covid-19 dengan Daring PjBL Berbasis Mind Mapping untuk Meningkatkan Hasil Belajar Biologi, Journal of Education Action Research 4(4) (2020) $393 . \quad$ DOI: http://www.doi.org/10.23887/jear.v4i4.28504 
[19] A. K. Hidayat, Penerapan Project Based Learning Pada Pendidikan Jasmani di Masa Social Distancing Pandemic Covid -19, JUARA Jurnal Olahraga 6(1) (2020) 1-11. DOI: http://www.doi.org/10.33222/juara.v6i1.1003

[20] Yustina, W. Syafii, R. Vebrianto, The effects of blended learning and project-based learning on pre-service biology teachers' creative thinking skills through online learning in the COVID-19 pandemic, Jurnal Pendidikan IPA Indonesia 9(3) (2020) 408-420. DOI: http://www.doi.org/10.15294/jpii.v9i3.24706

[21] U. A. Daulay, S. Syarifuddin, B. Manurung, Pengaruh Blended Learning Berbasis Edmodo dan Motivasi Belajar Terhadap Hasil Belajar IPA Biologi dan Retensi Siswa pada Sistem Peredaran Darah Manusia di Kelas VIII SMP Negeri 5 Medan, $\mathrm{PhD}$ Thesis, Universitas Medan, 2016.2 DOI: http://www.doi.org/10.24114/jpb.v6i1.4330

[22] W. Agustina F. Noor, Hubungan Hasil Belajar Dan Tingkat Berpikir Kreatif Siswa Dalam Pembelajaran Matematika, Math Didactic 2(3) (2016) 191-200. DOI: http://www.doi.org/10.33654/math.v2i3.49

[23] I. Jung, S. Choi, C. Lim, J. Leem, Effects of different types of interaction on learning achievement, satisfaction and participation in web-based instruction, Innovations in Education and Teaching International 39(2) (2002) 153162.

DOI:

http://www.doi.org/10.1080/1470329025293460 $\underline{3}$

[24] M. V. López-Pérez, M. C. Pérez-López, L. Rodríguez-Ariza, Blended learning in higher education: Students' perceptions and their relation to outcomes, Computers and Education 56(3) (2011) 818-826. DOI: http://www.doi.org/10.1016/j.compedu.2010.10. $\underline{023}$

[25] J. Lei, Quantity versus quality: A new approach to examine the relationship between technology use and student outcomes, British Journal of Educational Technology 41(3) (2010) 455-472. DOI: $\quad$ http://www.doi.org/10.1111/j.14678535.2009.00961.x

[26] A. Rahardjanto, Husamah, A. Fauzi, HybridPjBL: Learning outcomes, creative thinking skills, and learning motivation of preservice teacher, International Journal of Instruction
12(2)
(2019)
179-192.
DOI:

http://www.doi.org/10.29333/iji.2019.12212a

[27] M. Burns, Distance Education for Teacher Training: Modes, Models, and Methods. Washington, DC: Education Development Center, Inc., 2011.

[28] L. Somenarain, Student Perceptions and Learning Outcomes in Asynchronous and Synchronous Online Learning Environments in a Biology Course, 2010. Accessed: Oct. 21, 2020. [Online]. Available: http://jolt.merlot.org/vol6no2/somenarain_0610. $\underline{\mathrm{htm}}$

[29] C. Dziuban, C. R. Graham, P. D. Moskal, A. Norberg, N. Sicilia, Blended learning: the new normal and emerging technologies, International Journal of Educational Technology in Higher Education 15(1) (2018) 1-16. DOI: http://www.doi.org/10.1186/s41239-017-0087-5

[30] R. Soler, J. R. Soler, I. Araya, Subjects in the Blended Learning Model Design. TheoreticalMethodological elements, in: Procedia-Social and Behavioral Sciences, vol. 237, Elsevier, Amsterdam, 2017, pp. 771-777, DOI: http://www.doi.org/10.1016/j.sbspro.2017.02.12 $\underline{0}$

[31] Y. Yuliati, D. S. Saputra, Membangun Kemandirian Belajar Mahasiswa Melalui Blended Learning Di Masa Pandemi Covid-19, Jurnal Elementaria Edukasia 3(1) (2020) 142149.

[32] M. L. Hidayat, G. Nurcahyanto, Analisis Kesesuaian Google Classroom sebagai LMS pada Mata Kuliah Strategi Pembelajaran Biologi di FKIP UMS, in: Proceeding Biology Education Conference vol. 15, Universitas Sebelas Maret, Solo, 2018, pp. 572-576.

[33] F. Reimers, A. Schleicher, J. Saavedra, S. Tuominen, Supporting the continuation of teaching and learning during the COVID-19 pandemic. Annotated resources for online learning, 2020. [Online]. Available: https://www.oecd.org/education/Supporting-thecontinuation-of-teaching-and-learning-duringthe-COVID-19-pandemic.pdf 